\title{
RIPK3 wt Allele
}

National Cancer Institute

\section{Source}

National Cancer Institute. RIPK3 wt Allele. NCI Thesaurus. Code C51314.

Human RIPK3 wild-type allele is located in the vicinity of $14 q 11.2$ and is approximately 4 $\mathrm{kb}$ in length. This allele, which encodes receptor-interacting serine/threonine-protein kinase 3 protein, is involved in the induction of apoptosis and activation of the transcription factor NF-kappa-B. 